\title{
Employee Satisfaction with Training Opportunities and its Relation to Internal Marketing
}

\author{
Silvia, TREL'OVÁ, \\ Comenius University in Bratislava, Faculty of Management, Slovakia, \\ silvia.trelova@fm.uniba.sk \\ František, OLŠAVSKÝ \\ Comenius University in Bratislava, Faculty of Management, Slovakia, \\ frantisek.olsavsky@fm.uniba.sk
}

\begin{abstract}
The article aims to find a link between employee training and satisfaction with educational activities and marketing efforts of the organization. Qualification growth of employees is closely connected to the organization's success. Since obstacles in education hinder achieving desirable results, they need to be identified and overcome.

Theoretical background and knowledge was confronted with data collected in primary research. Interviewing was used as the method and questionnaire as the instrument. Data were statistically analysed and results of chi-square were calculated in software Statgraphics.

Testing the relationship between barriers in training involvement of employees and their socioeconomic characteristics proved that, gender, age, education level, sector of economy, length of current employment, and income satisfaction are independent. The only relevant dependence is apparent in case of fear of failure which is a barrier indicated for low income people.

This article clarifies the state of satisfaction with education possibilities of employees through identifying of the main barriers and concludes consequences for sustainable growth of organization.
\end{abstract}

Keywords: Labour market; Employee training; Barriers in education; Internal marketing; Sustainability

JEL Classification: M31, M53, K31

\section{Introduction}

As recent development shows, the success of an organization depends chiefly on the quality of human resources. Today, more than ever, educated employees are one of the key competitive advantages. It is the HR strategy and budget policy of a company that determines conditions for employee training. „In 
management studies, the assessment of human capital management and its development is considered a "paradigm shift" from the traditional concept of understanding employees as a cost item, towards the understanding of employees as assets requiring investment, which leads to an increase in their value." (Hvizdová, 2011).

The aim of the organization's training policy and educational programs is to ensure a qualified, trained and competent staff, whose presence is necessary in order for the organization to meet its current and future needs. It is assumed that employees will be willing and ready to learn, as well as able to take responsibility for their personal development. (Armstrong, 2007, p. 461) Job satisfaction surveys are often used as a criterion for the evaluation of corporate human resources policy and, hence, there is said to be a direct link between the level of satisfaction and employee care. To be more precise, the higher the job satisfaction is, the better the employees perceive the employer's care to be.

\section{Employee satisfaction}

A sustainable business success requires not only qualified and skilled employees, but also employee satisfaction, as recent studies emphasize. Employee satisfaction rate is a key factor not only for a high quality job performance, but also for overall working comfort. Since work is an inherent part of peoples' lives, it is indispensable for every employee to feel satisfied at work.

Job satisfaction is defined as a positive attitude of an employee towards his or her work and the conditions in which it is performed. In this article, we view job satisfaction in the light of a definition established by Daft (2014). According to Daft, job satisfaction equals the level of contentment a person feels towards his or her job. This very feeling is essentially based on an individual's subjective perception of satisfaction. Kociánová (2010, p. 35) states that job satisfaction is "an individual reaction to the subjectively perceived and experienced contexts of the job and the workplace; it is a result of an evaluation of the working conditions and circumstances; it is influenced by personality characteristics and individual preferences, and, last but not least, has a material impact on how work attitudes are shaped. "Hence, the form and degree of employee satisfaction varies over time.

„The concept of job satisfaction is usually understood and viewed from several perspectives. One of them highlights the substantial role of employee care provided by the company (working hours, work schedule, work safety, employee benefits). Job satisfaction is also strongly informed by the satisfaction brought 
about by task fulfilment itself, when the work becomes a source of self-realization. However, there is also a kind of satisfaction that gives the employee a feeling of false contentment with the achieved status quo and does not encourage him or her towards additional activity. While the former types of satisfaction are likely to become a driving force in the improvement of work results, the latter type of satisfaction may easily become a hindrance to further progress in any activity" (Olexová, Bosáková, 2006) Hence, employee satisfaction depends on a number of factors and their mutual interaction.

Matzler and Renzl (2006) note that employee satisfaction can be regarded as one of the most important driving forces of quality, customer satisfaction and productivity. Their definition brings us to think about internal marketing. As defined by Kotler and Armstrong (2011), internal marketing focuses on employee motivation and its supporting factors, such as teamwork, and eventually leads to the satisfaction of end customers. As a result, it is of paramount importance that the company hires the right people, since internal marketing is deeply intertwined with the external marketing, which informs the market of customers. The basic chain links of internal marketing are interconnected, meaning that the concept of internal customer concerns everyone within the organization and the employees are related to each other as customers. Internal marketing means that companies are oriented towards their customers and are motivated to provide them with a better service resulting in their satisfaction.

For the purposes of our paper, we made employee satisfaction our starting point, as it is directly connected to employee care provided by the company. After wages, employee care is the second criterion that people tend to use when comparing their company with another. As long as employees are satisfied with their working conditions (such as the possibility of career progress, the possibility of flexible work performance, financial evaluation, work team, the manager's personality, the style of leadership, professional growth and more), they are highly motivated, their work performance grows and the company prospers. It is not just the ideal theory but also the theory of sustainability for long term competitiveness on the market. Some sectors of the economy are existentially dependent on satisfied and highly motivated work force.

Career progress and staff development are two of several motivational factors which are related to the nature and content of work. They contribute to overall employee satisfaction and motivate employees towards performance. The possibility of career development and further training are particularly important especially for the highly qualified employees and managers. It is the support in process management and the investment in education and training that enables 
employees to see the long-term interest of the company. Thus, employees are more motivated and, by fulfilling their professional objectives, they also contribute to the achievement of the company's objectives.

\section{Employee Training}

In labour law terminology, the terms "deepening of qualification" and "increasing of qualification" are used in the context of employee training and they differ in content. "Deepening of qualification" is therefore a systematic training of employees with an aim to maintain, improve and update knowledge and skills once acquired and necessary in order to perform a specific job, while the employee's degree of qualification remains unchanged. In contrast to the deepening of qualification, which is regarded as a part of the work performance and represents company-wide training, "increasing of qualification" presents an obstacle in the employee's work performance, the level of education increases. The employer creates relevant conditions for employee training within the framework of corporate social policy. Employee training is regulated by $\S 153-155$ in Part VII of the Labour Code (Act no. 311/2001 Coll. Labour Code, as amended).

The nature of the training process, its level and its intensity can vary depending on the specific needs of the company. The development quality of the training program, the choice of place of training and the selection of an appropriate educational method for achieving the efficiency of the training process all play an important role in the process itself. The selection of an appropriate method of training is a key when it comes to the success of the training. We can conclude that a combination of various teaching methods is what brings about better results.

„If an employer provides opportunities for training, it communicates to the employees that their organization appreciates them, sees their potential, and much more. On the other hand, the employer is always glad to see that the employee wants to keep learning and to educate and develop himself or herself. The employee hereby signals the employer that he or she considers the work important and has interest in reaching his or her full potential at work. Any extra knowledge gained by the employee will move him or her forward and could be crucial for further career development or the very direction of his or her career." (Trel'ová, 2016, p. 364) „Employee education, its planning and its evaluation are a few of the key elements in organization development. However, the real effect is brought about by targeted training, which builds on the employees' work profiles along with the objectives of the organization and its management." (Birknerová, 2014) When it comes to the management of human resources, it is important to 
set specific objectives for employee training with regard for the future direction of the company.

\section{Employee training as an employee benefit}

Employee benefits are a form of additional rewarding. In order to motivate employees, it is necessary to provide them with employee benefits reflective of their needs and wishes. Employee benefits are traditionally not tied to the performance of the employee; the company grants them to employees simply for the sake of their status, or alternatively, they take into account the employees' status in the company, the length of their service or their achievements. The purpose is to increase the motivation for higher work performance and work satisfaction. The benefits can include corporate hospitality, health care, insurance and reinsurance, additional vacation, rewards for a certain number of years in the company, retirement rewards, cultural and sports events, recreation, allowance for transportation to work and so on. To ensure the required effectiveness of these benefits, it is recommended to use a system of flexible employee benefits (the socalled cafeteria system), which allows employees to choose a combination of benefits that best suit their individual needs.

Employee training is the most often provided benefit in Slovakia, as based on a research conducted by Merces.sk between 2007 and 2008 on a sample of 135 000 (profesia.sk, 2008). The research shows that in Slovakia, this benefit is used by three times more employees than in Hungary. Compared to Slovaks and Czechs, only a half of the employees in Hungary can make use of employee training. The survey also points out that as the demand for employee qualification grows, so does the proportion of respondents with the benefit of employee training, taking into account that this benefit is most often provided to the age group between 25 and 44 years of age. The results of the Merces.sk survey pointed out that the higher the education the employee has, the more non-financial benefits can be obtained alongside the job itself. Nearly $40 \%$ of respondents with second level of university education have access to employee training, while this benefit is only granted to $15 \%$ of respondents with basic education. As a result, more than a third of all employees with university education are provided further training by their employer. The benefit of employee training is provided mostly in the private sector with foreign participation, while in the state and the public sector, employee training ranks second among the benefits.

Another notable issue concerns the amount of employees continuing in vocational training after they are employed. Our survey showed that $42.7 \%$ of 
employees of all surveyed organizations are granted the opportunity of further vocational training. If it is an organization of $10-49$ employees, $28.1 \%$ of the employees receive further vocational training. If it is an organization of 50-249 employees, the percentage climbs up to $42.8 \%$, and if it is an organization of more than 250 employees, the percentage of employees who receive further vocational training spikes up to $51.5 \%$. Further vocational training is most often provided to current employees ( $62 \%$ of organizations) and in case of an internal reorganization aimed at improving the use of existing skills and abilities (57\%). Moreover, $53 \%$ of organizations stated recruitment of new employees with appropriate qualifications, while only $32 \%$ state recruitment combined with specific vocational training. This means that companies count on the fact that either they will take a new employee with an adequate level of competence, or they will train an already established employee. They are least likely to train a completely new employee. (Hrabinská, 2015; profesia.sk, 2008)

\section{Methodology of research}

Our analysis of the data collected in the primary research was based on the theoretical background as well as the results of the research conducted on a sample of 135000 interviewees by Merces.sk in 2007-2008. The primary research was based on the responses of 166 respondents, all of which were part-time students of business at the time. Just as expected, the majority of them had already possessed work experience and were simultaneously working and partaking in their studies. In order to collect data, we conducted interviews and created a questionnaire containing 22 partially open-ended questions. The collected data was statistically analysed and we used the software Stratgraphics to calculate the chi-square results. We chose the chi-square test as the statistical method, as it allowed us to test 7 factors - the classification characteristics of our respondents alongside 4 selected barriers of education. The exact $p$-Value is compared to the critical value of $5 \%$ and then the null hypothesis on independence can be rejected or not rejected.

\section{Findings}

This article is based on the premise that employee satisfaction in an organization is a key aspect in a highly competitive environment. Satisfaction with training activities contributes to the vitality of the relationship between a client and an employee. We also tested the null hypothesis by testing the relationship between barriers in training involvement of employees and their socio-economic characteristics such as gender, age, educational level, sector of economy, length 
of current employment, and income satisfaction. All the findings are presented in

Tab. 1. We can conclude that the null hypothesis at the level of confidence alpha 0,05 and the null hypothesis on independence can be rejected. All the socioeconomic characteristics of respondents are independent to the four tested types of barriers of education: lack of time, non-systematic training, fear of failure and insensitive approach of a supervisor. The only relevant dependence is apparent between the fear of failure and its close relation to income. The $p$-value of 0,0053 is below the critical limit, thus confirming this theory.

Table 1. Results from the tests of independence

\begin{tabular}{|c|c|c|c|c|c|}
\hline & & Lack of Time & tic Edu. & Fear of Failure & ervisor \\
\hline & Statistics & 3,433 & 0,182 & 0,238 & 3,18 \\
\hline Gender & DF & 1 & 1 & 1 & 1 \\
\hline & $p$-Value & 0,0639 & 0,6693 & 0,6253 & 0,0745 \\
\hline & Statistics & 8,926 & 7,873 & 2,877 & 2,385 \\
\hline Age & DF & 5 & 5 & 5 & 5 \\
\hline & $p$-Value & 0,112 & 0,1634 & 0,7189 & 0,7937 \\
\hline & Statistics & 0,882 & 0,696 & 3,319 & 0,963 \\
\hline Education & $\mathrm{DF}$ & 3 & 3 & 3 & 3 \\
\hline & $p$-Value & 0,8298 & 0,8742 & 0,345 & 0,8102 \\
\hline & Statistics & 2,774 & 0,013 & 1,63 & 1,073 \\
\hline Sector & DF & 1 & 1 & 1 & . \\
\hline & $p$-Value & 0,0958 & 0,9079 & 0,2017 & 0,3002 \\
\hline & Statistics & 6,141 & 1,158 & 1,312 & 1,195 \\
\hline How Long & DF & 3 & 3 & 3 & 3 \\
\hline & $\mathrm{p}$-Value & 0,1049 & 0,7631 & 0,7263 & 0,7541 \\
\hline & Statistics & 5,718 & 3,324 & 20,151 & 8,224 \\
\hline Nett Income & DF & 7 & 7 & 7 & 7 \\
\hline & $\mathrm{p}$-Value & 0,5731 & 0,8535 & 0,0053 & 0,3132 \\
\hline & Statistics & 1,164 & 4,746 & 4,787 & 0,276 \\
\hline Income Satisf. & DF & 3 & 3 & 3 & 3 \\
\hline & $\mathrm{p}$-Value & 0,7617 & 0,1913 & 0,1881 & 0,9646 \\
\hline
\end{tabular}

Source: own research in Statgraphics

In a more detailed analysis we can identify that especially low income employees reported a certain kind of fear of failure. With higher income the fear fades away. The results can be seen in Fig. 1. In the next step we discovered the frequency of the agreement to remain in the case of the deepening or increasing of qualification. The results are obvious: only 7 out of 159 respondents concluded the contract in the case of a deepening of qualification. In two cases, a dwelling time was established, namely 5 and 3 years. Moreover, only 3 out of 163 respondents partaking in increasing of qualification concluded the contract, but only 2 of them promised to stay, one for 5 years and another for 1 year. This approach of employers could lead to greater fluctuation of skilled labour force, which will be not sustainable for a longer period of time. 
Figure 1. Cross table for the fear of failure by net income

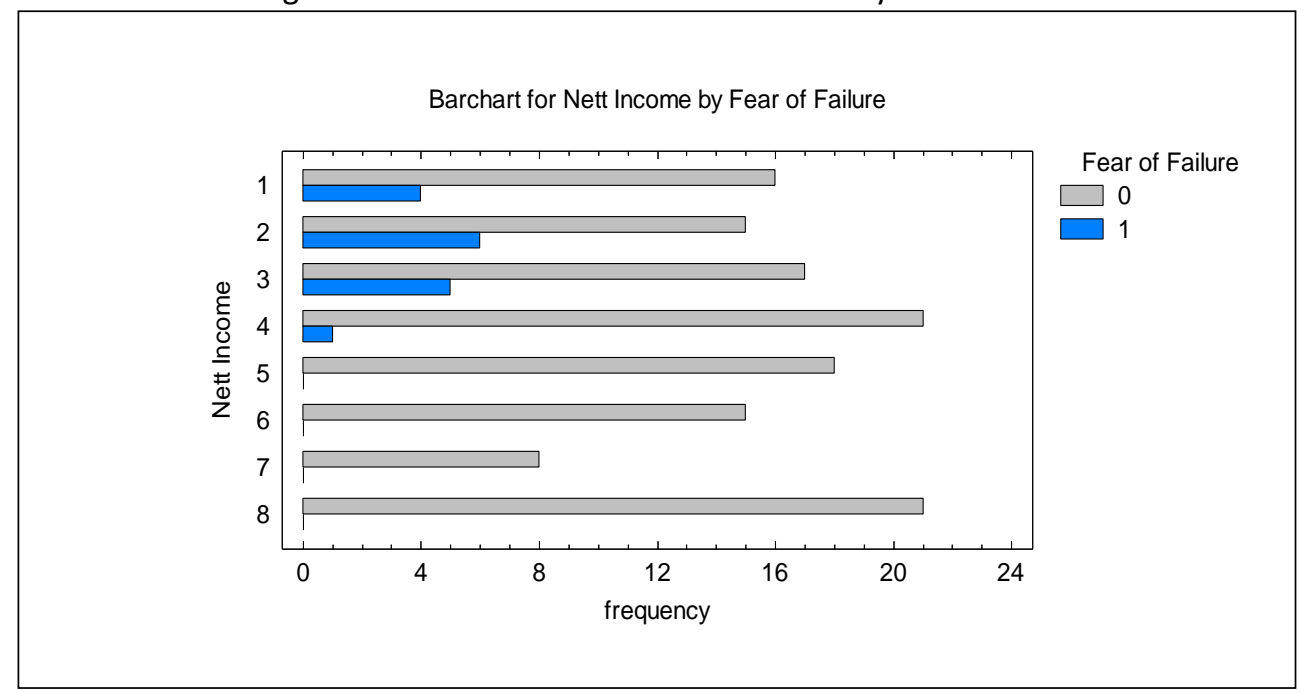

Source: author's interpretation

\section{Conclusions}

The overall satisfaction of an individual is a sum of several partial satisfactions, including labour satisfaction. Knowing the factors which influence employee satisfaction and motivation allows us to create an appropriate motivational program. It can affect the behaviour of an individual or a working group towards the development and efficient use of employee potential and towards responsible and high quality work with regard to the employees' personal objectives, while it can also affect interests of the whole company. This can be sustainably ensured through employee training oriented on internal marketing. It means that satisfied employees can be independent when taking proactive actions to ensure customer satisfaction of the organization.

In this context, findings by Dobre (2013, p. 53), who compared employee motivation and organizational performance, sound equally interesting. He stated that motivated and qualified workforce is essential for any company that wants to increase productivity and customer satisfaction. In this context, motivation means the willingness of an individual to make efforts and take actions towards organizational goals. The manager' goal is to find a means to create and sustain employee motivation. On one hand, managers should focus on reducing job dissatisfaction (working conditions, salary, supervision, relationship with colleagues), while on the other hand they should make use of motivational factors, such as achievement, recognition, responsibility and the work itself. Hlásna, Horváth \& Köksal (2013) stated that education can influence the quality of life. 
UNUM, an American company providing financial protection, discovered in their own research that out of the employees who rated their training benefits as fair/poor, only $27 \%$ rated their employer as an excellent/very good place to work (unum.com, 2012). However, out of those who rated their training benefits as excellent/very good, up to $82 \%$ rated their employer as an excellent/very good place to work. According to Veselý, Karovič \& Karovič (2016, pp. 280-284), the effects of training are visible at the state level too and it is described as a crucial element for the implementation of e-government.

As the statistical analysis shows, fear of failure is the only statistically significant barrier positively related to the low income groups of employees. Employers should understand this as a lack of self-confidence among their employees, which can be caused by various factors. The employer should address these reasons in this segment type. It should be noted that prove of independence of other kind of barriers to learning towards the respondents characteristics does not mean, they do not exist. Removing the barriers to training will allow both the employer and the employee to make a more effective use of training programs. The more necessary it is to prepare education programs while looking to the results of employee contracting in both cases: deepening and updating of education. To be aware of the legal background of rights and obligations persons involved in education program, it is not least important the economic statement too. The costs spent on education should be calculated for the purpose of return. Follow-up efficiency should be obvious. But as presented, only 7 or 3 out of the respondents reported some form of agreement with their employer. Perhaps employers do not realize that the time spent on training instead of work performance is a vital part of other direct costs. Most likely, Slovak employers are not interested in contractual coverage and expect their employees to stay loyal. However, the question is: Is this model sustainable? Do they stay and work or follow it's motivation? If we compare these results with the research conducted by Merces.sk, the most wide-spread benefit in Slovakia is employee training. The employers would have to be aware about it. Otherwise, we should perhaps consider the theory that training programmes provided for employees by Slovak organizations are not of a high quality or value.

As the results show, ongoing research will provide a more in-depth understanding of the effects of employee satisfaction on organizational training programs, which can lead the company towards higher performance and towards their employees becoming assets crucial for competitive prosperity. 


\section{References}

[1] Act no. 311/2001 Coll. Labour Code, as amended.

[2] Armstrong, M. (2007). Řizení lidských zdrojü. Grada Pulishing.

[3] Birknerová, Z. (2014). Rozvoj l'udských zdrojov - d'alšie vzdelávanie a výcvik zamestnancov. [ONLINE] Available at: http://www.promanager.sk/hr-management/rozvoj-ludskych-zdrojovdalsie-vzdelavanie-a-vycvik-zamestnancov. [Accessed 2 December 16].

[4] Daft, R. L. (2016). Management. Boundless Management. [ONLINE] available at: https://www.boundless.com/management/textbooks/boundless-managementtextbook/organizational-behavior-5/drivers-of-behavior-44/defining-job-satisfaction

2317247/. [Accessed 20 February 17].

[5] Dobre, O. I. (2013). Employee motivation and organizational performance. Review of Applied Socio-Economic Research, 5(1), pp. 53.

[6] Kociánová, R. (2010). Personální činnosti a metody personální práce. Grada Publishing.

[7] Kotler, P., \& Armstrong, G. (2011). Principles of Marketing. Prentice Hall.

[8] Hlásna, S., Horváth, M., \& Köksal, O. (2013). "Selected legislative components of legal guarantees applied to appropriate quality of life in the Slovak Republic." in: International Journal of Academic Research, part B, 5(3), pp. 497-502.

[9] Hrabinská, M., et al. (2015). Atraktívnost' vzdelávania na stredných odborných školách z pohl'adu žiakov 9. ročníka základných škôl. Výsledky dotazníkového prieskumu z roku 2014. Svet odborného vzdelávania a prípravy, 1(7), 36. [ONLINE] available at: http://www.rsov.sk/dokumenty/media/odborny_casopis/svet_odborneho_vzdelavania_7.pd f. [Accessed 7 August 16].

[10] Hvizdová, E. (2011). K problematike l'udského kapitálu z pohl'adu manažmentu znalostí. [ONLINE] available at: http://www.manazmentznalosti.eu/k-problematike-ludskeho-kapitaluz-pohladu-manazmentu-znalosti/. [Accessed 20 February 17].

[11] Najčastejšie poskytovaný benefit zamestnancom je vzdelávanie. (2008). [ONLINE] available at: http://www.profesia.sk/cms/dokumenty-na-stranke/informacie-a-analyzy/najcastejsieposkytovany-benefit-zamestnancom-je-vzdelavanie/41429. [Accessed 20 February 17].

[12] Matzler, K., \& Renzl, B. (2006). The Relationship between Interpersonal Trust, Employee Satisfaction, and Employee Loyalty, Total Quality Management \& Business Excellence, 17(10), pp. $1261-1271$

[13] Olexová, C., \& Bosáková, M. (2006). Motivácia a spokojnost' zamestnancov. [ONLINE], available at: http://www.epi.sk/odborny-clanok/Motivacia-a-spokojnost-zamestnancov.htm. [Accessed 20 February 17].

[14] Trel'ová, S. (2016). Vzdelávanie a rozvoj zamestnancov - kvalifikačné dohody. Education and training of employees - qualification agreements. MMK 2016. Magnanimitas, 356-365.

[15] unum.com. (2012). Beyond the usual benefits: 2012. The power of employee education to influence workforce satisfaction. [ONLINE] available at: http://forms.unum.com/StreamPDF.aspx?strURL=/FMS_099229-4. [Accessed 21 March 17].

[16] Veselý, P., Karovič, V., \& Karovič, V. (2016), Investments in education as a benefit for egovernment. Economics, management, Law: Innovation strategy Zhengshou: Henan Science and Technology Press, pp. 280-284. 